\title{
JUKMAS
}

\section{Perencanaan Pengendalian Kebisingan. Studi Kasus : Area Rewinder Machine Perusahaan Kertas}

\author{
Dinda Nur Aulia Septiani , Candra Nugraha \\ Program Studi Teknik Lingkungan Fakultas Teknik Sipil dan Perencanaan, Institut Teknologi Nasional \\ Jl. PH.H. Mustofa No.23, Cibeunying Kaler, Kota Bandung, 40124 \\ Email : auliadinda996@gmail.com
}

\begin{abstract}
Abstrak
Industrialisasi merupakan motor penggerak bagi kesejahteraan dan menempati urutan pertama dalam kehidupan masyarakat modern di negara berkembang. Salah satu faktor yang mempengaruhi kesehatan pekerja akibat kegiatan industri adalah kebisingan. Penelitian ini bertujuan untuk menganalisis tingkat kebisingan yang terjadi di area Rewinder Machine perusahaan kertas dan melakukan pengendalian terhadap kebisingan yang terjadi. Kebisingan diukur dengan menggunakan sound level meter selama 24 jam. Kebisingan pada 11 titik ukur melampaui nilai ambang batas NAB, sehingga diperlukan perencanaan pemasangan barrier. Material barrier yang terpilih adalah plexiglass dengan nilai NR sebesar 43,38 dBA. Nilai kebisingan setelah pemasangan barrier adalah $40 \mathrm{dBA}$ untuk titik 11, dan 42 dBA untuk titik 12. Selain itu reduksi kebisingan juga dapat dilakukan dengan Earplug yang dapat mengurangi kebisingan sebesar $33 \mathrm{~dB}$.
\end{abstract}

Kata Kunci : Kebisingan, Barrier, Rewinder Mesin, Reduksi.

\begin{abstract}
Industrialization is the driving force for welfare and ranks first in the life of modern society in developing countries. One factor that affects the health of workers due to industrial activities is noise. This study aims to analyze the noise levels that occur in the Rewinder Machine area and control the noise that occurs. Noise is measured using a sound level meter for 24 hours. Noise at 11 measuring points exceeds NAB's threshold value. So it is necessary to plan the installation of barriers. The selected barrier material is plexiglass with an NR value of $43.38 \mathrm{dBA}$. The noise value after barrier mounting is 40 $\mathrm{dBA}$ for point 11, and $42 \mathrm{dBA}$ for point 12 . In addition, noise reduction can also be done with Earplug which can reduce noise by $33 \mathrm{~dB}$.
\end{abstract}

Keyword : Noise, Barrier, Rewinder Machine, Reduction. 


\section{PENDAHULUAN}

Industrialisasi merupakan motor penggerak bagi kesejahteraan dan menempati urutan pertama dalam kehidupan masyarakat modern di negara berkembang, industri sangat mempengaruhi pembangunan dan kebutuhan masyarakat. Seiring dengan perkembangan zaman, bahan dan alat produksi yang digunakan semakin beragam dan canggih untuk memudahkan dan mengurangi aktivitas manusia. Semua kegiatan industri yang dilakukan akan mempengaruhi kesehatan pekerja, dan salah satu faktor yang mempengaruhi kesehatan pekerja adalah kebisingan. Kebisingan adalah bunyi yang tidak diinginkan dari usaha atau kegiatan dalam tingkat dan waktu tertentu yang ditimbulkan oleh perusahaan atau kegiatan pada tingkat dan waktu tertentu, yang dapat mengganggu kesehatan manusia dan kenyamanan lingkungan. Kebisingan merupakan bunyi atau suara yang tidak dikehendaki, berbentuk gelombang longitudinal, berasal dari sumber bunyi atau suara yang merambat melalui udara atau medium rambat lainnya [1].

Pekerja industri wajib untuk memperhatikan kesehatan dan keselamatan dalam segala aktivitas kerja yang dilakukan. Karyawan adalah aset berharga perusahaan, oleh karena itu, dalam hal ini kesehatan dan keselamatan pekerja menjadi sangat penting [2]. Sebanyak 4-5 juta orang, $12-15 \%$ dari keseluruhan pekerja terpapar bising pada tingkat $85 \mathrm{~dB}$ atau lebih di negara Jerman dan negara-negara berkembang lainnya [3]. Salah satu masalah kesehatan kerja yang paling umum terjadi di Amerika Serikat selama lebih dari 25 tahun adalah gangguan pendengaran, karena setiap tahunnya sekitar 30 juta orang pekerja terpajan kebisingan yang berbahaya [4].

Perusahaan yang menjadi objek penelitian ini yaitu salah satu perusahaan yang bergerak di bidang industri kertas. Setiap kegiatan produksi yang dilakukan perusahaan memiliki risiko bagi para pekerjanya karena suara yang dihasilkan dari mesin-mesin produksinya. Salah satunya yaitu kegiatan produksi di Rewinder Machine.

Risiko dari kegiatan industri tersebut dapat dihindari dengan berkerja sesuai prosedur yang ditetapkan, maka pemerintah telah menyusun, dan menetapkan kebijakan terkait kebisingan, berdasarkan kebijakan tersebut pemaparan kebisingan di industri dengan tingkat kebisingan $85 \mathrm{~dB}$ (A) adalah untuk 8 jam kerja per hari atau 40 jam kerja per minggu [5].

\section{METODE}

Penelitian ini dilakukan di area rewinder machine perusahaan kertas yang terletak di daerah Karawang, Jawa Barat. Pada penelitian ini akan dirancang barrier yang berfungsi 
mengurangi kebisingan pada area tersebut. Langkah pertama yang dilakukan yaitu mengukur kebisingan menggunakan sound level meter selama 24 jam sesuai dengan standar pada KepMenLH No. 48 Tahun 1996 Tentang Baku Tingkat Kebisingan [6]. Sound level meter alat ukur dengan basis pengukuran elektronik, berfungsi mengukur kebisingan antara 30-130 $\mathrm{dB}$ dalam satuan $\mathrm{dB}(\mathrm{A})$ dari frekuensi 20-20.000 $\mathrm{Hz}$ [7]. Pengukuran dilakukan pada 12 titik ukur yang ditentukan berdasarkan lokasi dimana operator bekerja di area Rewinder Machine. Penentuan titik ukur ditentukan dengan metode grid [8].

Hasil pengukuran kebisingan dibandingan dengan Nilai Ambang Batas (NAB) yang merupakan intensitas tertinggi dari suara dan merupakan nilai rata-rata yang masih dapat diterima oleh tenaga kerja tanpa menimbulkan risiko hilangnya daya dengar [9]. NAB tersebut berdasarkan PerMenaKer No. 5 Tahun 2018, NAB yang digunakan yaitu 85 dBA karena operator mesin pada area Rewinder Machine bekerja selama 8 jam/hari. Kontur kebisingan dibuat dengan menginput koordinat $X, Y, Z$ ke dalam golden software surfer yang merupakan salah satu perangkat lunak yang digunakan untuk membuat peta kontur yang berdasarkan pada grid [10]. Peta kebisingan ruang dibuat menggunakan software AutoCAD 2014. Material yang dipilih ditentukan dengan menghitung nilai Transmission Loss (TL) yaitu rugi transmisi suatu partisi [11], dan Noise Reduction (NR) yang merupakan pengurangan bunyi antar ruang dengan memperhitungkan nilai transmisi [11] dari masing-masing bahan. Berdasarkan nilai TL dan NR yang didapat maka dapat ditentukan jenis material yang tepat untuk mengurangi tingkat kebisingan pada area rewinder machine perusahaan kertas. Ketinggian barrier ditentukan dengan variasi ketinggian menggunakan metode Maekawa [12]. Reduksi yang dihasilkan dari penggunaan APDT (Alat Pelindung Diri Telinga) dihitung menggunakan persamaan pada PerMenKes No. 70 tahun 2016 Tentang Standard dan Persyaratan Kesehatan Lingkungan di Tempat Kerja [13]. Berikut merupakan persamaannya :

dBA Efektif $=$ dBA pajanan awal $-\{[$ NRR APDT 7] $\} \times 50 \%$

Dimana :

dBA Efektif = Pajanan yang diterima setelah penggunaan APDT (dBA)

dBA pajanan awal $=$ Pajanan yang diterima sebelum penggunaan APDT $(\mathrm{dBA})$

NRR APDT $=$ Noise Reduction Rate APDT $(\mathrm{dB})$ Faktor koreksi $=7$

\section{HASIL DAN PEMBAHASAN}

\section{Data Tingkat Kebisingan}

Kebisingan diukur pada rentang waktu yang telah ditentukan. Berikut merupakan waktu pengambilan data kebisingan : 


\begin{tabular}{|c|c|c|c|}
\hline $\begin{array}{c}\text { Titik } \\
\text { Pengukuran }\end{array}$ & $\begin{array}{l}\text { LSM } \\
\text { (dBA) }\end{array}$ & $\begin{array}{c}\text { NAB (Nilai } \\
\text { Ambang Batas) } \\
\text { Kebisingan } \\
\text { (PerMenaKer } \\
\text { No. } 5 \text { Tahun } \\
\text { 2018) (dBA) }\end{array}$ & Keterangan \\
\hline Titik 1 & 86,6 & 85 & $\begin{array}{c}\text { Melampaui } \\
\text { NAB }\end{array}$ \\
\hline Titik 2 & 87,8 & 85 & $\begin{array}{c}\text { Melampaui } \\
\text { NAB }\end{array}$ \\
\hline Titik 3 & 89,4 & 85 & $\begin{array}{l}\text { Melampaui } \\
\text { NAB }\end{array}$ \\
\hline Titik 4 & 91,7 & 85 & $\begin{array}{c}\text { Melampaui } \\
\text { NAB }\end{array}$ \\
\hline Titik 5 & 89,8 & 85 & $\begin{array}{l}\text { Melampaui } \\
\text { NAB }\end{array}$ \\
\hline Titik 6 & 88,7 & 85 & $\begin{array}{l}\text { Melampaui } \\
\text { NAB }\end{array}$ \\
\hline Titik 7 & 85,5 & 85 & $\begin{array}{c}\text { Melampaui } \\
\text { NAB }\end{array}$ \\
\hline Titik 8 & 89,4 & 85 & $\begin{array}{c}\text { Melampaui } \\
\text { NAB }\end{array}$ \\
\hline Titik 9 & 88,3 & 85 & $\begin{array}{c}\text { Melampaui } \\
\text { NAB }\end{array}$ \\
\hline Titik 10 & 88,1 & 85 & $\begin{array}{c}\text { Melampaui } \\
\text { NAB }\end{array}$ \\
\hline Titik 11 & 83,3 & 85 & Dibawah NAB \\
\hline Titik 12 & 85,4 & 85 & $\begin{array}{l}\text { Melampaui } \\
\text { NAB }\end{array}$ \\
\hline
\end{tabular}

Tabel 1 Waktu Pengambilan Data

Sumber: KepMenLH No. 48 Tahun 1996 Tentang Baku Tingkat Kebisingan.

Diperoleh 120 data hasil pengukuran selama 10 menit dengan pembacaan setiap 5 detik. Data tersebut diolah menjadi data kebisingan 24 jam (LSM) dalam satuan dB. Skala decibel (dB) diperoleh dari 10 kali logaritma [14]. Data tersebut diolah menggunakan persamaan :

$\mathrm{L}_{\mathrm{SM}}=10 \log 1 / 24\left(16 \times 10^{0.1 \mathrm{Ls}}+8 \times 10^{0.1(\mathrm{Lm}+5)}\right)$ $\mathrm{d} B(A)$

\section{Dimana :}

$L_{S}=$ Leq di siang hari $[d B(A)]$

$\mathrm{L}_{\mathrm{M}}=$ Leq di malam hari $[\mathrm{dB}(\mathrm{A})]$

$L_{S M}=$ Leq pada pengukuran 24 jam $[\mathrm{dB}(\mathrm{A})]$

Hasil perhitungan dengan persamaan tersebut adalah seperti yang ditunjukkan pada Tabel 2.
Tabel 2 Nilai LSM Pada Setiap Titik Ukur

\begin{tabular}{|c|c|c|c|}
\hline Leq & Waktu & Mewakili & Keterangan \\
\hline \multirow{5}{*}{ LS } & Pukul 07.00 & $\begin{array}{l}\text { pukul 06.00- } \\
09.00\end{array}$ & $\mathrm{Ta}=3 \mathrm{jam}$ \\
\hline & Pukul 10.00 & $\begin{array}{l}\text { pukul 09.00- } \\
11.00\end{array}$ & $\mathrm{~Tb}=2$ jam \\
\hline & Pukul 14.00 & $\begin{array}{l}\text { pukul } 11.00- \\
17.00\end{array}$ & $\mathrm{Tc}=6 \mathrm{jam}$ \\
\hline & Pukul 20.00 & $\begin{array}{l}\text { pukul } 17.00- \\
22.00\end{array}$ & $\mathrm{Td}=5$ jam \\
\hline & \multicolumn{3}{|l|}{16 Jam } \\
\hline \multirow{3}{*}{ LM } & Pukul 23.00 & $\begin{array}{l}\text { pukul 22.00- } \\
24.00\end{array}$ & $\mathrm{Te}=2 \mathrm{jam}$ \\
\hline & Pukul 01.00 & $\begin{array}{l}\text { pukul 24.00- } \\
03.00\end{array}$ & $\mathrm{Tf}=3 \mathrm{jam}$ \\
\hline & Pukul 04.00 & $03.00-06.00$ & $\mathrm{Tg}=3 \mathrm{jam}$ \\
\hline LSM & \multicolumn{3}{|l|}{24 Jam } \\
\hline
\end{tabular}

Berdasarkan Tabel 2 dapat diketahui terdapat 11 titik ukur yang memiliki nilai LSM melampaui NAB (Nilai Ambang Batas). Nilai LSM tertinggi ada pada titik 4 yaitu sebesar 97,1 $\mathrm{dBA}$, hal tersebut disebabkan titik 4 berada diantara cutter kedua alat Rewinder Machine, sehingga ketika cutter memotong roll yang sudah digulung ulang, kebisingan dari kedua cutter pada mesin terakumulasi. Nilai LSM terendah berada pada titik 11 yaitu sebesar 83,3 dBA, hal tersebut disebabkan titik 11 berjarak cukup jauh dari kedua Rewinder Machine. 


\section{Perencanaan Barrier}

Barrier akan dibuat di depan titik 11, dan 12 karena area pada titik tersebut cukup luas

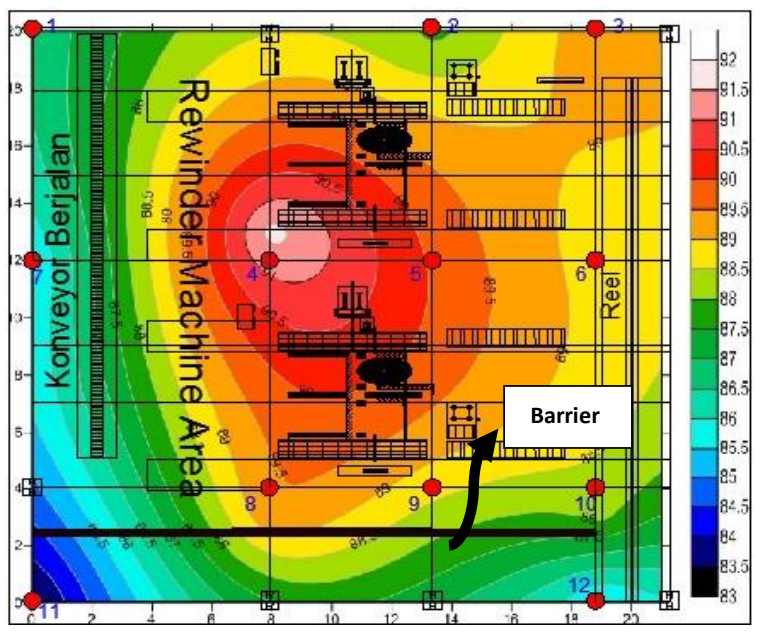

Gambar 1 Rencana Peletakkan Barrier

dan memungkinkan untuk dibuatnya barrier.

Sumber: Hasil Perhitungan 2020.

Berdasarkan nilai LSM yang telah didapat, maka nilai kebisingan yang melampaui NAB perlu diturunkan sehingga berada di bawah nilai NAB dengan mengurangi nilai LSM dengan nilai NAB. Diperlukan material yang dapat mereduksi kebisingan, dan material barrier yang akan dibuat harus dapat menahan bunyi yang datang. Pada penelitian ini akan dipilih 4 jenis material untuk dijadikan bahan barrier, yaitu wood, plywood, plexiglass, dan gypsum. Keempat material tersebut dipilih karena mudah didapatkan di pasaran. Berikut merupakan spesifikasi dari keempat material tersebut berdasarkan guidelines book adalah sebagai berikut [15] :
Tabel 3 Spesifikasi Material Barrier

\begin{tabular}{|c|c|c|}
\hline \multirow{2}{*}{ Material } & Thickness & Surface Density \\
\hline & $\mathrm{mm}$ & $\mathrm{Kg} / \mathrm{m} 2$ \\
\hline Wood & 25 & 18 \\
\hline Plywood & 25 & 16,1 \\
\hline Plexiglass & 6 & 7,3 \\
\hline Gypsum & 10 & 9,1 \\
\hline
\end{tabular}

Pemilihan material yang layak untuk digunakan sebagai bahan barrier dilakukan dengan menghitung nilai TL (Transmission Loss) dan nilai NR (Noise Reduction) dari bahan tersebut menggunakan Persamaan 3 dan Persamaan 4 [11].

$T L=(20 \log W)+(20 \log f)-$ C............................(3)

Dimana :

$\mathrm{TL}=$ Transmission Loss $(\mathrm{dB})$

$\mathrm{f}=$ Frekuensi $(\mathrm{Hz})$

$\mathrm{W}=$ Surface Density Material $\left(\mathrm{Kg} / \mathrm{m}^{2}\right)$

$\mathrm{C}=$ Nilai koefisien yang telah ditentukan yaitu

47

NR $=$ TL

Dimana :

NR : Noise Reduction (dB)

$\mathrm{TL}=$ Transmission Loss $(\mathrm{dB})$

Nilai TL dan NR dihitung berdasarkan frekuensi yang digunakan yaitu $125 \mathrm{~Hz}, 200 \mathrm{~Hz}$, $500 \mathrm{~Hz}, 1000 \mathrm{~Hz}$, dan $2000 \mathrm{~Hz}$. Frekuensi 
tersebut dipilih karena pada frekuensi tersebut adalah rentang frekuensi bicara manusia [16].

Tabel 4 Transmission Loss (TL) pada Masing-

\section{Masing Material}

\begin{tabular}{|c|c|c|c|c|c|c|c|}
\hline \multirow{2}{*}{ Material } & \multirow{2}{*}{$\begin{array}{c}\text { Thickne- } \\
\text { ss }\end{array}$} & $\begin{array}{c}\text { Surface } \\
\text { Density } \\
\text { (W) }\end{array}$ & \multicolumn{5}{|c|}{ Transmission Loss (TL) dB } \\
\cline { 3 - 8 } & $\mathbf{m m}$ & $\mathbf{K g} / \mathbf{m 2}$ & $\mathbf{1 2 5}$ & $\mathbf{2 0 0}$ & $\mathbf{5 0 0}$ & $\mathbf{1 0 0 0}$ & $\mathbf{2 0 0 0}$ \\
\hline Wood & 25 & 18 & 20 & 24 & 32 & 38 & 44 \\
\hline Plywood & 25 & 16.1 & 19 & 23 & 31 & 37 & 43 \\
\hline Plexiglass & 6 & 7.3 & 12 & 16 & 24 & 30 & 36 \\
\hline Gypsum & 10 & 9.1 & 14 & 18 & 26 & 32 & 38 \\
\hline
\end{tabular}

Berdasarkan Tabel 4 nilai Transmission Loss tertinggi dihasilkan oleh bahan material wood dengan nilai TL 44 dB pada frekuensi 2000 $\mathrm{Hz}$.

Tabel 5 Noise Reduction pada Masing-Masing Material

\begin{tabular}{|c|c|c|c|c|c|c|c|}
\hline \multirow{2}{*}{ Material } & \multirow{2}{*}{$\begin{array}{c}\text { Thickne- } \\
\text { ss }\end{array}$} & $\begin{array}{c}\text { Surface } \\
\text { Density }\end{array}$ & \multicolumn{5}{|c|}{ Noise Reduction (NR) dB } \\
\cline { 4 - 8 } & $\mathrm{mm}$ & $\mathrm{Kg} / \mathrm{m} 2$ & 125 & $\mathbf{2 0 0}$ & $\mathbf{5 0 0}$ & 1000 & 2000 \\
\hline Wood & 25 & 18 & 26 & 30 & 38 & 44 & 50 \\
\hline Plywood & 25 & 16,1 & 25 & 29 & 37 & 43 & 49 \\
\hline Plexiglass & 6 & 7,3 & 18 & 22 & 30 & 36 & 42 \\
\hline Gypsum & 10 & 9,1 & 15 & 24 & 32 & 38 & 44 \\
\hline
\end{tabular}

Sumber: Hasil Perhitungan 2020.

Berdasarkan Tabel 5 nilai Noise Reduction tertinggi dihasilkan oleh bahan material wood dengan niai NR $50 \mathrm{~dB}$ pada frekuensi $2000 \mathrm{~Hz}$. Namun karena mempertimbangkan faktor ketahanan bahan dan faktor safety karena mesin bekerja selama 24 jam tanpa henti, maka dipilihlah material plexiglass sebagai material pembuat barrier, karena material plexiglass bening (tidak berwarna) sehingga pekerja masih dapat mengawasi mesin yang bekerja.

\section{Penentuan Ketinggian Barrier}

Ketinggian barrier perlu ditentukan agar barrier bekerja efektif, dan suara dipastikan tidak lolos. Penentuan ketinggian barrier akan dilakukan dengan simulasi, dan dihitung dengan metode Maekawa, dengan variasi ketinggian 3,5 m, 4 m, dan 4,5 m [17]. Berikut merupakan persamaan pada metode Maekawa [12] :$$
\partial=(a+t+
$$$$
\text { b) - d }
$$

Dimana :

$\partial=$ path length difference $(\mathrm{m})$

$a=$ jarak sumber bising ke puncak barrier $(m)$

$b=$ jarak puncak barrier ke pendengar $(m)$

$d=$ jarak sumber bising ke pendengar $(m)$

$\mathrm{t}=$ ketebalan material yang akan digunakan $(\mathrm{m})$

$f=c / \lambda$

Dimana :

$\mathrm{f}=$ Frekuensi $(\mathrm{Hz})$

$\lambda=$ Panjang gelombang bunyi $(\mathrm{m})$

$\mathrm{c}=$ kecepatan medium rambat $(\mathrm{m} / \mathrm{s})$

$B=10 \log (3+40 \quad \partial / \lambda)$

$B=$ Nilai pengurangan bunyi $(\mathrm{dB})$

$\partial=$ path length difference $(m)$

$\lambda$ : Panjang Gelombang $(m)$ 
Tabel 6 Simulasi Ketinggian Barrier dengan Metode Maekawa

\begin{tabular}{|c|c|c|c|c|}
\hline \multicolumn{5}{|c|}{ Simulasi 1} \\
\hline \multicolumn{5}{|c|}{$\mathrm{h}$ barrier $=3.5 \mathrm{~m}$} \\
\hline Titik & $\begin{array}{c}\text { Nilai Intensitas Kebisingan } \\
\text { (dBA) }\end{array}$ & $\lambda(\mathrm{m})$ & $\partial(m)$ & $B(d B)$ \\
\hline 11 & 83,3 & 0,17 & 0,49 & 20,7 \\
\hline 12 & 85,4 & 0,17 & 0,49 & 20,7 \\
\hline \multicolumn{5}{|c|}{ Simulasi 2} \\
\hline \multicolumn{5}{|c|}{$\mathrm{h}$ barrier $=4 \mathrm{~m}$} \\
\hline Titik & $\begin{array}{c}\text { Nilai Intensitas Kebisingan } \\
\text { (dBA) }\end{array}$ & $\lambda(\mathrm{m})$ & $\partial(m)$ & $B(d B)$ \\
\hline 11 & 83,3 & 0,17 & 1,182 & 24,5 \\
\hline 12 & 85,4 & 0,17 & 1,182 & 24,5 \\
\hline \multicolumn{5}{|c|}{ Simulasi 3} \\
\hline \multicolumn{5}{|c|}{$h$ barrier $=4,5 \mathrm{~m}$} \\
\hline Titik & $\begin{array}{l}\text { Nilai Intensitas Kebisingan } \\
\text { (dBA) }\end{array}$ & $\lambda(\mathrm{m})$ & $\partial(m)$ & $B(d B)$ \\
\hline 11 & 83,3 & 0,17 & 1,319 & 25 \\
\hline 12 & 85,4 & 0,17 & 1,319 & 25 \\
\hline
\end{tabular}

Sumber: Hasil Perhitungan 2020.

Berdasarkan tabel Tabel 6, nilai reduksi paling besar adalah $25 \mathrm{~dB}$ pada simulasi 3 dengan ketinggian barrier 4,5 m. Maka ketinggian barrier yang akan digunakan yaitu 4,5 m karena dapat mereduksi kebisingan lebih tinggi daripada ketinggian pada simulasi lainnya. Ketinggian dari barrier harus melampaui ketinggian sumber agar tidak terjadi kebocoran suara [18].

Tabel 7 Pajanan yang Diterima Pekerja Setelah

\begin{tabular}{|c|c|c|c|c|c|}
\hline Titik & $\begin{array}{l}\text { LSM } \\
\text { (dBA) }\end{array}$ & NAB & $\begin{array}{c}\text { Jenis } \\
\text { Pengendalian }\end{array}$ & $\begin{array}{l}\text { Pajanan yang } \\
\text { diterima } \\
\text { Setelah } \\
\text { Pengendalian } \\
\text { (dBA) }\end{array}$ & $\begin{array}{c}\text { Keteranga- } \\
n\end{array}$ \\
\hline 11 & 83.3 & 85 & \multirow{2}{*}{$\begin{array}{l}\text { Barrier } \\
\text { Plexiglass } \\
\text { (Nilai } \\
\text { Reduksi } \\
43.38 \mathrm{dBA} \text { ) }\end{array}$} & 40 & \multirow[b]{2}{*}{$\begin{array}{c}\text { Dibawan } \\
\text { Nilai NAB }\end{array}$} \\
\hline 12 & 85.4 & 85 & & 42 & \\
\hline
\end{tabular}

Adanya Barrier

Sumber: Hasil Perhitungan 2020.

Berdasarkan Tabel 7 pajanan yang diterima setelah adanya barrier plexiglass pada titik 11 adalah $40 \mathrm{dBA}$, dan pada titik 12 adalah $42 \mathrm{dBA}$. Berdasarkan hasil tersebut maka kebisingan yang ada telah berada dibawah NAB
PerMenaKer No. 5 Tahun 2018 Tentang Keselamatan dan Kesehatan Kerja Lingkungan Kerja.

\section{Reduksi Kebisingan Oleh APDT (Alat Pelindung Diri Telinga)}

Pengendalian kebisingan yang telah dilakukan oleh perusahaan terkait pada area rewinder machine adalah penggunaan Alat Pelindung Diri Telinga (APDT) berupa ear plug. Alat Plindung Diri (APD) merupakan alternatif terakhir yang dilakukan apabila alternatifalternatif yang diberikan sebelumnya belum dapat mengurangi bahaya dan dampak yang mungkin timbul [19]. Berdasarkan PerMenKes No. 70 tahun 2016, Alat Pelindung Diri Telinga (APDT) berupa ear plug memiliki NRR (Noise Reduction Rate) sebesar $33 \mathrm{~dB}$. Reduksi kebisingan dihitung dengan persamaan :

dBA Efektif $=$ dBA pajanan awal $-\{[$ NRR APDT7] $\} \times 50 \%$

Dimana :

dBA Efektif = Pajanan yang diterima setelah penggunaan APDT ( $d B A$ )

$\mathrm{dBA}$ pajanan awal = Pajanan yang diterima sebelum penggunaan APDT ( $d B A$ ) NRR APDT $=$ Noise Reduction Rate APDT (dB)

Faktor koreksi $=7$ 
Tabel 8 Reduksi Kebisingan Oleh Ear Plug

\begin{tabular}{|c|c|c|c|c|c|}
\hline Titik & $\begin{array}{c}\text { Leq } \\
\text { Day } \\
\text { (dBA) }\end{array}$ & NAB & $\begin{array}{c}\text { Jenis } \\
\text { Pengendalian }\end{array}$ & $\begin{array}{l}\text { Pajanan } \\
\text { yang } \\
\text { diterima } \\
\text { (dBA) }\end{array}$ & Keterangan \\
\hline 1 & 86,6 & 85 & \multirow{10}{*}{$\begin{array}{l}\text { Penggunaan } \\
\text { APDT Berupa } \\
\text { Earplug (NRR } \\
\quad 33 \mathrm{~dB} \text { ) }\end{array}$} & 73,6 & \multirow{12}{*}{$\begin{array}{l}\text { Dibawah } \\
\text { Nilai NAB }\end{array}$} \\
\hline 2 & 87,8 & 85 & & 74,8 & \\
\hline 3 & 89,4 & 85 & & 76,4 & \\
\hline 4 & 91,7 & 85 & & 78,7 & \\
\hline 5 & 89,8 & 85 & & 76,8 & \\
\hline 6 & 88,7 & 85 & & 75,7 & \\
\hline 7 & 85,5 & 85 & & 72,5 & \\
\hline 8 & 89,4 & 85 & & 76,4 & \\
\hline 9 & 88,3 & 85 & & 75,3 & \\
\hline 10 & 88,1 & 85 & & 75,1 & \\
\hline 11 & 83,3 & 85 & \multirow{2}{*}{$\begin{array}{c}\text { Barrier } \\
\text { Plexiglass } \\
\text { (Nilai } \\
\text { Reduksi } \\
43.38 \mathrm{dBA} \text { ) }\end{array}$} & 40 & \\
\hline 12 & 85,4 & 85 & & 42 & \\
\hline
\end{tabular}

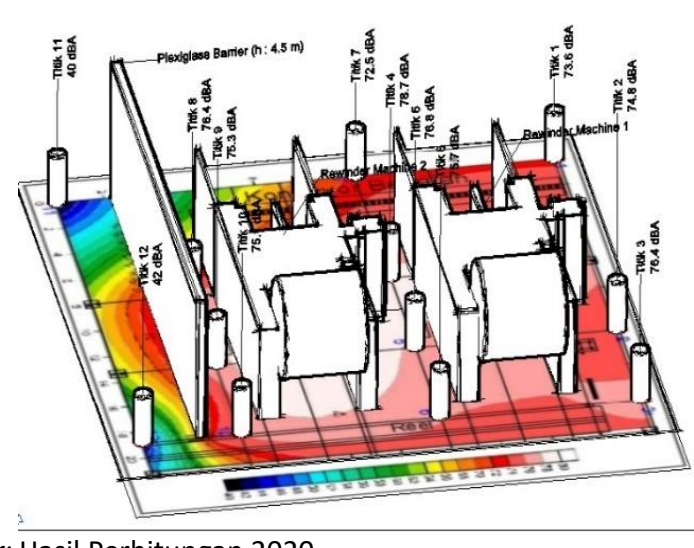

Sumber: Hasil Perhitungan 2020.

Berdasarkan Tabel 8 , hasil perhitungan menunjukkan nilai pajanan yang diterima setelah menggunakan ear plug berada dibawah nilai NAB, berdasarkan PerMenaKer No. 5 Tahun 2018 yaitu 85 dBA. Penggunaan earplug cukup efektif dalam mereduksi kebisingan yang diterima pekerja. Pekerja pada titik 11 dan 12 tidak perlu menggunakan earplug karena operator yang bekerja pada titik 11, dan 12 terhalang oleh barrier.

\section{KEBISINGAN SETELAH PENGENDALIAN}

\begin{tabular}{|c|c|c|c|c|c|}
\hline Titik & $\begin{array}{c}\text { Leq } \\
\text { Day } \\
\text { (dBA) }\end{array}$ & NAB & $\begin{array}{c}\text { Jenis } \\
\text { Pengendalian }\end{array}$ & $\begin{array}{l}\text { Pajanan } \\
\text { yang } \\
\text { diterima } \\
\text { (dBA) }\end{array}$ & Keterangan \\
\hline 1 & 86,6 & 85 & & 73,6 & \\
\hline 2 & 87,8 & \multirow{2}{*}{\multicolumn{4}{|c|}{$\begin{array}{l}\text { Gambar } 2 \text { llustrasi Area Rewinder Machine Setelah } \\
\text { Pemasangan Barrier dan Penggunaan Ear plug (3D) }\end{array}$}} \\
\hline 3 & 89,4 & & & & \\
\hline 4 & 91,7 & כס & \multirow{7}{*}{$\begin{array}{c}\text { Penggunaan } \\
\text { APDT Berupa } \\
\text { Earplug (NRR } \\
\quad 33 \mathrm{~dB} \text { ) }\end{array}$} & 10,1 & \multirow{7}{*}{$\begin{array}{l}\text { Dibawah } \\
\text { Nilai NAB }\end{array}$} \\
\hline 5 & 89,8 & 85 & & 76,8 & \\
\hline 6 & 88,7 & 85 & & 75,7 & \\
\hline 7 & 85,5 & 85 & & 72,5 & \\
\hline 8 & 89,4 & 85 & & 76,4 & \\
\hline 9 & 88,3 & 85 & & 75,3 & \\
\hline 10 & 88,1 & 85 & & 75,1 & \\
\hline
\end{tabular}

menggunakan barrier, dan menghitung paparan yang diterima dengan penggunaan ear plug, maka nilai kebisingan yang ada telah menurun.

Tabel 9 Nilai Pajanan Kebisingan Setelah dilakukan Pengendalian

Sumber: Hasil Perhitungan 2020.

Berdasarkan Tabel 9 penggunaan barrier plexiglass yang memiliki ketebalan 6 $\mathrm{mm}$; surface density $7,3 \mathrm{~kg} / \mathrm{m} 2$, dengan ketinggian barrier 4,5 $\mathrm{m}$, dan penggunaan ear plug dalam upaya pengendalian kebisingan efekif mereduksi kebisingan sehingga kebisingan yang timbul tidak membahayakan bagi kesehatan pendengaran pekerja karena berada dibawah NAB berdasarkan PerMenaKer No. 5 Tahun 2018 Tentang Keselamatan dan Kesehatan Kerja Lingkungan Kerja yaitu 85 dBA. Sumber: Hasil Perhitungan 2020.

\section{SIMPULAN}

Kesimpulan dari penelitian ini yaitu pengendalian kebisingan di area Rewinder Machine dapat dilakukan dengan pemasangan barrier dan penggunaan Earplug. 
Mempertimbangkan faktor safety yaitu kondisi di lapangan, dan faktor ketahanan bahan, terpilihlah material plexiglass bening sebagai bahan barrier agar mesin tetap bisa terpantau oleh operator, plexiglass yang memiliki ketebalan $6 \mathrm{~mm}$; dan surface density $7,3 \mathrm{~kg} / \mathrm{m}^{2}$ dengan nilai TL sebesar $36 \mathrm{~dB}$, dan nilai NR sebesar $42 \mathrm{~dB}$ sebagai material barrier yang akan dirancang.

Reduksi kebisingan yang dihasilkan oleh penggunaan earplug dengan NRR sebesar $33 \mathrm{~dB}$ cukup efektif dalam mengurangi kebisingan di area Rewinder Machine.

\section{SARAN}

Pemasangan barrier dengan material plexiglass direkomendasikan pada area rewinder machine dan perusahaan-perusahaan lain yang memiliki nilai tingkat kebsingan yang melampaui Nilai Ambang Batas (NAB) kebisingan pada aktivitas produksinya agar kebisingan yang terjadi dapat dikurangi.

\section{DAFTAR PUSTAKA}

[1] Suma'mur.2009. Hygine Perusahaan dan Keselamatan Kerja.Jakarta : CV. Sagung Seto.

[2] Tjiptoherijanto, P. 2001. Proyeksi penduduk, angkatan kerja, tenaga kerja, dan peran serikat pekerja dalam peningkatan kesejahteraan. Majalah Perencanaan Pembangunan, 23, 1-10.
[3] Masir, N., Ghoddoosi, M., Mansor, S., Abdul-Rahman, F., Florence, C. S., Mohamed-Ismail, N. A., Md-Latar, N. H. 2012. RCL2, a potential formalin substitute for tissue fixation in routine pathological specimens. Histopathology, 60(5), 804-815.

[4] Minggarsari, H. D.2019. Hubungan Intensitas Kebisingan Dengan Keluhan Auditori Pada Pekerja Bagian Produksi Pabrik Fabrikasi Baja. Binawan Student Journal, 1(3), 137-141.

[5] Peraturan Menteri Ketenagakerjaan dan Transmigrasi Republik Indonesia No. 5 Tahun 2018 tentang Keselamatan dan Kesehatan Kerja Lingkungan, 2018.

[6] Keputusan Menteri Negara Lingkungan Hidup No. 48 Tahun 1996 Tentang: Baku Tingkat Kebisingan, 1996.

[7] Buchla, D., \& McLachlan, W.1992. Applied electronic instrumentation and measurement. Pearson College Division.

[8] Sasmita, A., Asmura, J., \& Ambarwati, N. R.2018. Pengendalian Kebisingan Dengan Metode Conceptual Model Di Pabrik Kelapa Sawit Pt. Tunggal Perkasa Plantations. Jurnal Sains dan Teknologi, 17(2), 61-68.

[9] Suheryanto, R.2004.Pengaruh Kebisingan Mesin Pabrik Tekstil Terhadap Pendengaran Karyawan [Skripsi].Surabaya (ID): Universitas 
[10] Munirwansyah, M., Sundary, D., \& Nugraha, G. S.2013. Interpretasi Bearing Layer (Kontur Lapisan Tanah Keras) Di Bawah Permukaan Dengan Program Surfer (Kecamatan: Syiah Kuala-Ulee Kareng-Kuta Alam). Jurnal Teknik Sipil, 2(3), 269-280.

[11] Mayangsari, A. P.2009. Perancangan Barrier Untuk Menurunkan Tingkat Kebisingan Pada Jalur Rel Kereta Api Di Jalan Ambengan Surabaya Dengan Menggunakan Metode Nomograph: Surabaya: Digilib. ITS.

[12] Ariyadi, R. G.2016. Peningkatan Atenuasi Penghalang Bising Dalam Mengendalikan Kebisingan Akibat Lalu Lintas Di Sekolah Dasar Negeri Siwalankerto I Surabaya Menggunakan Metode Simulasi 2 Dimensi. Institut Teknologi Sepuluh Nopember Surabaya.

[13] Peraturan Menteri Kesehatan Republik IndonesiaNo. 70 Tahun 2016 tentang Standar dan Persyaratan Kesehatan Lingkungan Kerja, 2016.

[14] Malau, N. D., Manao, G. R. S., \& Kewa, A.2017. Analisa Tingkat Kebisingan Lalulintas di Jalan Raya. EduMatSains: Jurnal Pendidikan, Matematika dan Sains, 2(1), 89-98.

[15] SAR, G.2003. Guidelines on Design of Noise Barriers Environmental Protection Department and Highways Department January
[16] Arista, E., Guna, R. R. D. P. B., \& Double, M. K. K. A. A.2017. Track Jalur Kereta Api Di Area Pemukiman Lintas Manggarai-Bekasi. Jurnal Perkeretaapian Indonesia, 1(2), 97-104.

[17] OECD.1995.Repeated dose oral toxicity test method, In: OECD Guidelines for testing of chemicals, No 407, Organization for Economic Cooperation and Development, Paris, France.

[18] Depkes RI.1999. Rencana Pembangunan Kesehatan Menuju Indonesia Sehat 2010, Jakarta.

[19] Mashuri, M.2007. Penggunaan Akustika Luar-Ruangan dalam Menanggulangi Kebisingan pada Bangunan. SMARTek, $5(3)$.

[20] Rahmawati, Dini.2015. Fakto-faktor yang Berhubungan dengan Gangguan Pedengaran Pada Pekerja di Departemen Metal Forming dan Heat Treatment PT. Dirgantara Indonesia (Persero) Tahun 2015, Skripsi, UIN Syarif Hidayatullah, Jakarta. 